\title{
Appraising the Role of Afrimation (African- Animation) in Promoting Africa's Rich Cultural Heritage in a Digital Age
}

\author{
Joseph Izang Azi \\ Rochester Institute of Technology (RIT), Rochester, New York \\ $\&$ \\ Department of Industrial Design, Ahmadu Bello University, Zaria, Nigeria \\ azijoe86a2000@yahoo.com; jia7050@g.rit.edu
}

\begin{abstract}
In spite of its longstanding history, Africa's animation industry's impact on its socio-eco-cultural development has been very inconsequential to say the least. This article discusses six (6) contemporary 'indigenous' Afrimation projects that have potential of being highly innovative in the digital technology arena, as a medium for promoting the African Renaissance agenda. These projects include: Kabongo; Tinga Tinga Tales; Zambezia; The Lion of Judah; Magic Cellar and Interactive Child Learning Aid Project (i-CLAP) Model. The paper also highlights key issues in the relevant to the development of African animation like the design techniques, business models and partnership strategies and the implication of this new digital technology trends on Africa's development and future.
\end{abstract}

\section{Keywords:}

Globalization, ICT, Culture, Local Content, Afrimation, Business Strategy

\section{Introduction}

It is noted that globalization has brought about greater interdependency and interconnectedness in advancing international trade and cultural exchange among nations of the world [8]. Christopher Chase-Dunn in [48] distinguished at least five different dimensions of globalization namely: (i) economic (ii) political (iii) ecological constraints (iv) cultural values and institutions and (v) globalization of communication. In spite of the significant multidimensional transformation that globalization is exerting on the world, it is unfortunate that the impact is yet to be made fully manifest on Africa's development. For billions of the world's people, business-driven globalization means uprooting old ways of life and threatening livelihoods and culture [47 \& 23].

In mitigating the bottleneck hindering the efforts of nations like Africa to be substantially felt on the global development arena; components of its rich culture could be repackaged and disseminated using relevant digital technology devices. This would impact Africa's socio-ecocultural development and consequently serve as impetus for Africa to play its part towards globalization agenda. Research reveals that globalization can be partly a process to acquire local technology and science and to support local product development initiatives. This position is 
International Journal of Computer Graphics \& Animation (IJCGA) Vol.2, No.2/3, July 2012

significant in the steps towards technology transfer made by developing nations like China, Japan, India, Brazil and so on. Yuan [62] argues that "it is imperative for developing countries, including the least developed (LDCs), to build research and development (R\&D) capacities, without which they are likely to miss opportunities to upgrade their technologies, move up the development ladder and catch up with developed countries."

While it has been discovered that Africa's priceless artifacts have been inexplicably carted out and now constitute parts of the collections in major world museums, vast tangible and intangible relics of the heritage still exist in communities around Africa. The diversity of Africa's cultural traditions includes: art, music, games, fashion, architecture and oral literature, which serve to reinforce existing religious and social patterns [42]. Azi [7] speculates that this heritage has formed the bedrock for Africa's uniquely established political system, religious beliefs, language structure and indigenous technological practices. Unfortunately, elements of this unique tradition like the practice of oral storytelling, music and folklore are in danger of being lost [49]. Notably, the process of 'cultural globalization' warrants the broadcast of cultures globally, this is facilitated by the movement of people, objects, signs and symbols encapsulated in travels, book, music, art and crafts, films and other cultural artifacts.

Against which premise, this article posits that repackaging relevant aspects of Africa's unique cultural heritage as animated digital contents, would in no small way be vital in preserving and promoting the culture both locally and internationally. It would offer a medium for the diversification of the digital contents that makeup the global digital tapestry. Adams and Goldbard [1] ascertain that "diversity is a social asset and part of the cultural commonwealth requiring protection and nourishment." Olajide [45] argues in fact that "Africans could attain the desired industrial and technological breakthroughs, by looking inward and making their culture the core of national planning." The current accomplishment of Nigerian home movie industry attests to this assertion. Given its capacity to produce well over a thousand movies yearly, netting in 2008 an estimated US $\$ 250$ to US $\$ 300$ million [42]. In a global cinema survey released by UNESCO in 2009, Nigeria's Nollywood ranked second largest in the world after Bollywood [20 \& 4].

Although, this attainment may be considered exceptional in the evolution of Africa's digital contents, it is no doubt that the industry's technical competence, management structure and revenue generation capacities require upgrading to meet modern standards. In spite of the industry's net worth, its percentage contribution, by the 2011 estimated US $\$ 103$ billion global filmed entertainment industry's output [37], is below zero. It is almost comparable to the cost of producing Pirates of the Caribbean: At World's End, Hollywood's most expensive film in 2010 [61]. The challenge therefore is towards boosting the value of Africa's creative industry by improving its quality and global competitiveness.

Furthermore, Kaloki [33] notes that Africa's total contribution in the global creative economy is almost negligible. Mbaye [34] affirms that the relatively marginal contribution of Africa to the world export of cultural goods is less than $1 \%$. However, the creative industry's predicted growth over the next 20 years is to be dominated by small businesses, with criteria tied closely to the ICT sector overlapping around animation, audio, visual, etc. and focused on digital content and to a lesser extent, the cultural sub-sectors [17]. It is no doubt that with appropriate technical support, Africa's creative industry has the potential to propel its socio-eco-cultural progress to unimaginable heights. This can be achieved through advancing a tangible ICT-based creative 
International Journal of Computer Graphics \& Animation (IJCGA) Vol.2, No.2/3, July 2012

resource that propagates Africa's unique cultural expression, reflecting its attitudes, beliefs, opinions, ideas, languages, values and artistic craftsmanship.

\section{Problem Statement}

While in advanced societies, governments is continually challenged to enhance social progress and foster prosperity for its citizens [41], unfortunately, Africans (especially children) experience complex developmental environment hostile to ingenuous processes. This phenomenon may not be unconnected with Africa's multifaceted predicaments like: wars, diseases (e.g. HIV/AIDS, malaria and polio), famine, corruption, political instability and crime. Howard Gardner's view of intelligence is "the ability to solve problems through creating products of value in one's own culture" [36]. The challenge therefore is to initiate an African Renaissance agenda capable of positively growing the underexploited local content creative industry, towards transforming the people's lives using ICT devices.

Economic Development Directorate [17] argues that although, technologies around connectivity (e.g. internet and mobile telephony) and their convergence are still largely in their infancy, these industries have enormous growth potential to transform societies and economies. Mutua [38] agrees that digital content is a major contributor and driver of economic growth in developing countries. This may however be true in the case of countries like India, China, Japan, Malaysia, Brazil and Philippine, Pickett [46] asserts that India is probably the most popular destination for IT offshore outsourcing. On the other hand, Africa's digital contents are unsophisticated in terms of technical skills and equipment usage, hence too crude to possess a value proposition capable of attracting foreign investments or patronage in the international market place. Balancing Act [9] affirms that African films producers have often found it hard to get global distribution. Unfortunately, rich film and television markets support high value productions [12].

The focus of this article therefore is to examine the structure of Africa's contemporary digital content development industry (i.e. Afrimation), especially with a view to evaluating its potential as a medium for promoting the African Renaissance agenda. Against which backdrop, it is essential foremost to recognize that being able to create unique contents addresses only a fraction of the challenge. Pertinent also is competence in: (a) re-using the contents in diverse technologybased applications (based on the convergence principle) and (b) developing the most appropriate business strategies (i.e. marketing, management, legal and public relations etc.). Mbaye [34] attests to the fact that, talent alone is not sufficient to build a competitive creative economy; there must be institutional, as well as political interventions.

\section{Aim and Objectives}

The aim of this paper is to examine the role of Afrimation in promoting Africa's rich cultural heritage, using relevant digital technology resources. The objectives include to:

(i) Assess the role of digital technology in repackaging Africa's rich cultural heritage;

(ii) Determine the contribution of Africa's rich cultural heritage in diversifying global digital technology contents; 
International Journal of Computer Graphics \& Animation (IJCGA) Vol.2, No.2/3, July 2012

(iii) Appraise the role of the Afrimation industry in enhancing Africa's socioeconomic renaissance in a digital technology era; and

(iv) Examine significant technical elements that are essential towards reinforcing Africa's digital content development industry.

\section{Repackaging Africa's Cultural Heritage in a Digital Age}

According to Bhattacharjee [12] the impression given by some Western scholars is that the African continent made very little or no contributions to civilization and that its people are naturally primitive. Moreover, that this has unfortunately become the basis for racial prejudice and negative perception directed against all people of African origin. This is in spite of the fact that Africa's human and material resources were used in automating essential aspects of the 'civilization', like the Industrial Revolution. Encarta [19] describes as 'primitive', cultures with crudely simple technologies for providing comfort and efficiency. Of course, it can be hypothetically argued that, with the exception of Africa, early civilizations globally have shown evidences of fundamental paradigm shifts in their cultural practices and social philosophies, to address new technological challenges. On the contrary, Africans seems rather to be perpetual endusers of western technologies, still unable to grow a uniquely indigenous media half a century after independence.

This might not be unconnected to widespread corruption, mismanagement and adherence to ritualistic practices, as against economic prudency and adherence to scientific methods. Half a century after independence, this phenomenon makes it impossible to transform Africa's indigenous knowledge system (AIKS) into a contemporary technology-based system, in spite of all efforts emanating within and outside. These acts are considered highly retrogressive and deterrent to growth and development processes in a $21^{\text {st }}$ century civilization. However, positive cultural practices should be harnessed using digital technology resources and garnered into modernized local contents. Unfortunately, in embracing western ideologies by African pioneers of modern civilization, the process involved shrewd suppression of major aspects of Africa's uniquely established indigenous systems [7]. Frost [22] argues that embracing the symbols of American "pop" culture makes young people feel empowered and define a new youth elite.

Interestingly, this research is among series of local initiatives that advocate a paradigm shift, through repackaging components of Africa's traditional folkloric practices as digital technology contents of high artistic merit. The outcome of which can be varieties of indigenous contents disseminated via local and national TV networks, free-to-air satellite channels, Internet and as mobile phones apps. According to Discop [] Africa's population of 840 million has household TV ownership of 42 million. Mobile phone subscriptions have grown faster in Africa than in any other region in the world since 2003 [55]. Internet Usage Statistics [29] also asserts that Africa's internet usage had grown from 4.5 million in 2000 to 139.9 million in 2011. ICT is a sector that is expected to continue to grow driven by developments in new technology; trends include a shift towards activities such as software, media, content and services [16].

Further, these developments together with the advent of network technologies such as broadband Internet, digital interactive television, and mobile and wireless communications, are creating huge new markets for ICT. Unfortunately, apart from assemblage, no single electronic hardware (like $\mathrm{TV}$, video or cell phone) has been successfully developed fully from Africa, yet the region offers a very viable market for these devices. However, worthwhile efforts are being made towards 
International Journal of Computer Graphics \& Animation (IJCGA) Vol.2, No.2/3, July 2012

software development, notable among them are applications such as: Buni TV a new pan-African web and mobile video distribution platform created by Buni Media, specifically focused on contents created in Africa or about Africa. It is aimed at revolutionizing the distribution of African video [8]. Essoungou [21] observes that "in South Africa, MXit, a free instant messaging application with an estimated 7 million users, is the most popular local social networking platform." Also that, "from Abidjan and Accra to Lusaka and Nairobi, African programmers are designing, testing and launching new homegrown platforms and tools to keep the African online conversation going".

Also, is an initiative like: UNICEF's sponsored Sara cartoon project which offered a mouth piece for the girl-child against gender discrimination and other unwholesome African customs and traditions [33]. According to Iwunze [30] Mark of Uru was created as an animated web-based series by an upcoming animator Obinna Onwuekwe; it is an African folkloric and mythological tale on the challenges of young Azuka. Similarly, the Tinga Tinga Tales produced by Kenya's Homeboyz Company, integrated both the traditional Tinga Tinga painting techniques of Tanzania and African traditional animal folktales [50]. All of which present assorted contemporary indigenous platforms for repackaging and propagating Africa's rich cultural heritage, for local and international TV audiences and mobile internet social network applications.

\section{Defining Local (Digital) Content}

Local content concept range from variety of products that emanate from specific localities, like oil and gas from Brazil, automotive parts from China, creative contents from India or South Africa. This article however is centered on creative contents. Bhattacharjee [11] defines local content as "programming produced under the creative control of nationals of a country." For instance, in Australia, a local animated program's requirement stipulates that the production designer, character designer, supervising layout artist, supervising storyboard artist or key background artist should be Australian. Other countries may have even more detailed definitions of local content. Mutua [37] considers local content as content produced locally and consumed locally or (and) globally. However, given the circumstances of content development in Africa local content as referred in this article may constitute any digital technology content that integrates relevant components of Africa's cultural heritage, packaged as: computer software, film, animation, cinema, CD/DVD, video or computer games, mobile phone apps. Against which backdrop, the concept of Afrimation is considered to be local digital contents directly or indirectly predisposed to Africa's development and characterized by one or more of the following factors:

(a) Cultural relevance, in terms of:
(i) Theme
(ii) Persona
(iii) Symbols and Imagery
(iv) Scenery and
(v) Language, accent and sound track

(b) Economic viability, in terms of:
(i) Employment generation
(ii) Commercializability
(iii) Advancement of industrialization
(iv) Export earnings 
International Journal of Computer Graphics \& Animation (IJCGA) Vol.2, No.2/3, July 2012

(c) Social significance, in terms of:

(i) Propagation of international partnership or collaboration

(ii) Alternative media for information, entertainment and enlightenment

(iii) Diversification of global digital contents

The aforementioned characteristics are to apply in defining afrimation, whether the projects are fully or partly funded and or produced by Africans in Africa or outside. An example, according to Wallace [58], is the film Kirikou and the Sorceress (1994) was produced in France by Michel Ocelot and has an African theme. Giannalberto Bendazzi referred to Ocelot as "a great white African animation director." It is noted that culture is Kirikou's main African characteristic. Below is a discourse on significant local content initiatives, highlighting their capacity to advance Africa's socio-eco-cultural development in this era of digital technology revolution.

\section{Afrimation in the Diversification of Global Digital Contents}

This paper considered 6 contemporary local content projects namely: Kabongo, Tinga Tinga Tales, Zambezia, The Lion of Judah, Magic Cellar and Interactive Child Learning Aid Project (iCLAP) Model. The projects were selected on the basis of common characteristics, such as: (a) African Art and Design Styles: The designs were made to depict Africa art styles (in terms of theme, colours and symbols); (b) Standard Designs: They were also original, highly innovative, contemporary and the continent's best animated contents for: education (e.g. Tinga Tinga Tales and i-CLAP), entertainment (e.g. Zambezia, The Lion of Judah) and enlightenment (e.g. Kabongo) and (c) International Strategic Partners: They had technical and strategic partnership with international organizations. Against which characteristics, details on the 6 selected afrimation projects are presented below:

(i) Kabongo - Kabongo is an animated series produced by Pictoon Studio in Senegal, which was set up in 1998 by Pierre Sauvalle together with his Co-Director Aïda Ndiaye (a businesswoman) [60]. Sauvalle [49] argues that "unless we know how to sell our culture, others will sell it for us." In view of which philosophy Pictoon studio initiated an animated series, narrating the adventures of an African hero Kabongo and his singing monkey Golo (shown in Figure 2). He seeks a worthy child to whom he can pass his art and skills. Interestingly, Kabongo was the first 2D animation series to be entirely made in Africa and in December 2003 the project enjoyed an international broadcast on the Canal France International (CFI) satellite service. Pierre Block de Freiberg the Programming Director of CFI asserts "it is a magnificent, very ambitious and very African series" [49]. While the Kabongo series advocates the transmission of Africa's cultural heritage to the world via the digital media, Pictoon's production of The General Assembly of Diseases enlightens the African audiences on the dangers of diseases (see Figure 2). 
International Journal of Computer Graphics \& Animation (IJCGA) Vol.2, No.2/3, July 2012
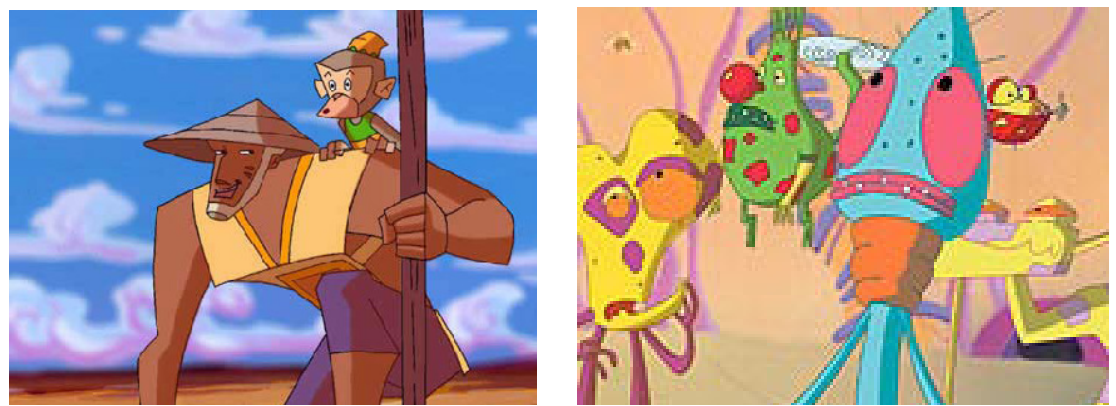

Figure $1 \&$ 2: Kabongo and Golo his Singing Monkey \& The General Assembly of Diseases by Pictoon

Sources: www.wipo.int/wipo_magazine/en/2005/05/article_0004.html \& http://wn.com/The_General_Assembly_of_Diseases_Scenerios_from_the_Sahel (Original Idea by Mamadou Macki Bah, aged 17, from Kayes, Mali) [26]

(ii) Tinga Tinga Tales - The Homeboyz Entertainment Company in Kenya produced the Tinga Tinga Tales, a very colorfully rendered children's folktale series. According to Tiger Aspect [52] Claudia Lloyd (Figure 2 below) promoted the 52 episodes programme at the Disney Playhouse and CBeebies, it adapted the painting technique originated by Edward S. Tingatinga. Figure 4 below is a poster showing a cross-section of its unique $2 \mathrm{D}$ animated characters used in telling the African animal stories. The project was spearheaded by Tiger Aspect Productions in the UK. Bynum [13] affirms that Tinga Tinga Tales incorporated a vivid visual taste suitable to its inquisitive, homegrown animal folk stories like 'how the leopard got its spots' and 'why the zebra has stripes'. He affirms that the animated series was sold in 2010 to BBC and Disney.
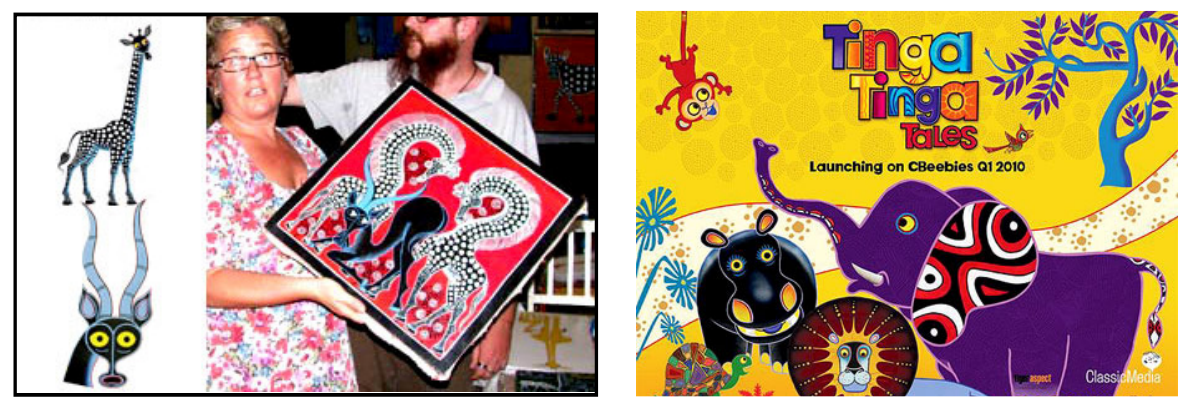

Figure 3 \& 4: Claudia Lloyd Posing with a Traditional Tinga Tinga Painting \& Figure 4: A Cross-Section of Tinga Tinga Tales Characters

Source: http://en.wikipedia.org/wiki/Tinga_Tinga_Tales \& http://www.google.com.ng/imgres?imgurl=http://www.frankierants.com/wpcontent/uploads/2011/03/tinga-tinga-tales/ [28]

(iii) Zambezia - Triggerfish Studio in South Africa released within the American Film Market the promo of its first 3D animated feature film called Zambezia. Edward Noeltner, the sales agent of CMG disclosed that "distributors have been very excited by the 'quality' and 'standard' they've seen in the promo and sales negotiations are underway" [54]. The film tells the story of Kai (shown in Figure 5 below, in a flight scene) - a naïve, but high-spirited young falcon who travels to the bird city of Zambezia to discover the truth about his origins. Further, in defending the city he learns how to be part of a community [55]. Of course, citizenship and communalism are two fundamental virtues of the Africa cultural philosophy which Kai displayed. It is noteworthy that Triggerfish Studio received funding from the Industrial Development 
Corporation (IDC), Department of Trade and Industry (DTI) and National Film and Video Foundation (NFVF).

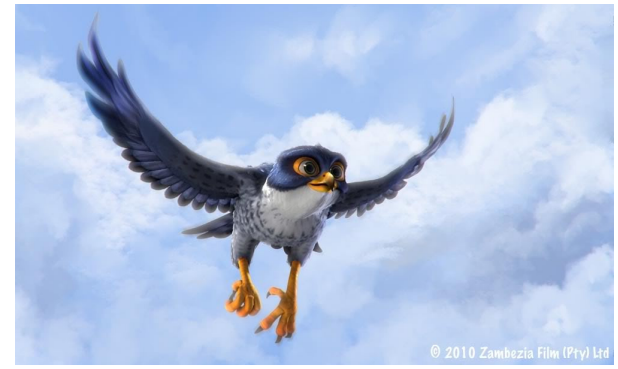

Figure 5: Zambezia, Kai in the Bright Blue Sky in a Flight Scene (2008)

Source: www.animationsa.org/community/press-releases/triggerfish/zambezia-takes-flight [54]

(iv) The Lion of Judah - The Lion of Judah is South Africa's first full length CGI film being produced by Sunrise Productions South Africa, which was carried out in collaboration with Animated Family Films Incorporated, Florida. According to Squidoo [51] the film was released in 2010, conveying a heart-warming account of the Easter Story as seen through the eyes of a bold lamb called Judah (Georgina Cordova). The 3D animated movie is a roaring adventure with Judah (a heroic lamb); Slink (a rat and leader of the group); Jack (a donkey with an attitude); Boss (a street-smart raven); Esmay (a motherly cow) and a few others (Figure 6) [15]. Furthermore, Greenleaf [25] affirms that all casts are stable animals and featured the voice talents of Academy Award-winners: Ernest Borgnine, Georgina Cordova, Scott Eastwood, Michael Madsen and others.

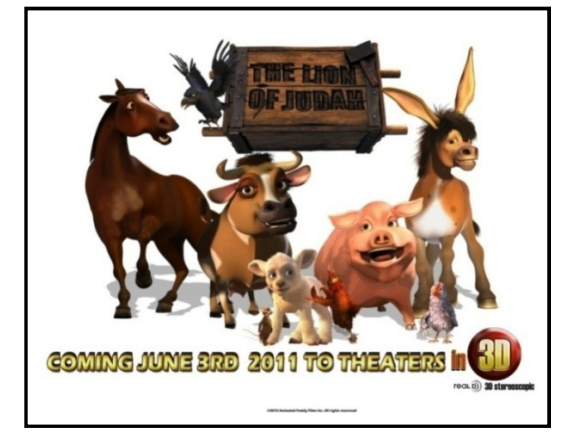

Figure 6: Poster I, Lion of Judah (2010)

Source: www.lionofjudahthemovie.com/

(v) Magic Cellar - Magic Cellar is a highly successful South African 3D animated series produced by Morula Pictures, it was the first of its kind based on African culture successfully sold to the US Home Box Office (HBO) channel. HBO Family [25] affirms that the folktales were collected from community elders. Mfundi Vundla, 58, who owns Johannesburg's Morula Pictures, South Africa's largest black-led studio, said his productions are meant to counter the perception of "Africans as unsophisticated, superstitious idiots who visited witch doctors to solve problems." It employs 60 people and dozens of actors. Parents need to know that this imaginative animated series exposes kids to African folktales that are acted out by a multicultural group of characters, typifying the South African multiracial characteristic. Figure 7 shows a cross-section of these characters. The show celebrates the oral history that is central to African traditions and draws parallels between the tribal stories and scenarios that kids will relate to, like "disputes 
International Journal of Computer Graphics \& Animation (IJCGA) Vol.2, No.2/3, July 2012

among friends" and "feeling let down by a parent." Lessons in patience, generosity, fairness and honesty are central to this worthwhile series [2].

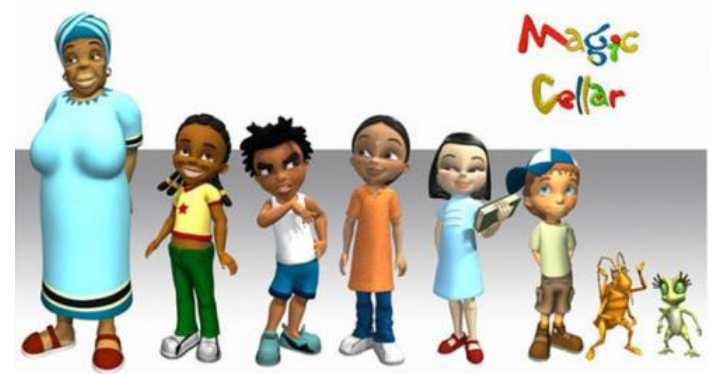

Figure 7: Magic Cellar, the First African Cultural 3D Animated Series (2006)

Source: http://www.animationsa.org/article/magic-cellar-acquired-hbo-historic-sale [27]

(vi) Interactive Child Learning Aid Project (i-CLAP) Model - The i-CLAP model project was initiated in 2002 as an indigenous interactive (non-linear) multimedia model for enhancing early childhood education customized for Nigeria. It was developed as a Ph.D. research by Joseph Izang Azi, a Lecturer with Department of Industrial Design, Ahmadu Bello University and Graphic Design Consultant with Colour-Waves Communications Inc. both in Zaria, Nigeria. The project was carried out partly in Nigeria and the USA (at the College of Imaging Arts and Sciences, Rochester Institute of Technology, Rochester, New York) [5]. The i-CLAP model constitutes of 4 main parts namely:
(A) Non-Interactive (Linear):
(i) Wazobia
(B) Interactive (Non-Linear):
(ii) Match Pictures to Alphabets;
(iii) Finding the Alphabets and
(iv) Fun with Colors

While Wazobia is a non-interactive (linear) animated clip of an African boy going to school (Figure 8 below, Wazobia in the village: concept and character created in 2005), the animation is used to captivate learners' attention into the project using the principle of learning 'from' computer. This is an aspect of i-CLAP model's linear animation. On the other hand i-CLAP model's 'Match Pictures to Alphabets' (Figure 9); 'Finding the Alphabets' and 'Fun With Colors' are interactive (non-linear) educational contents that integrate game elements into learning. The goal of the 2D animation project includes teaching children basic skills in: letters of the alphabet, objects and color recognition and the appreciation of local cultural concepts. 
International Journal of Computer Graphics \& Animation (IJCGA) Vol.2, No.2/3, July 2012
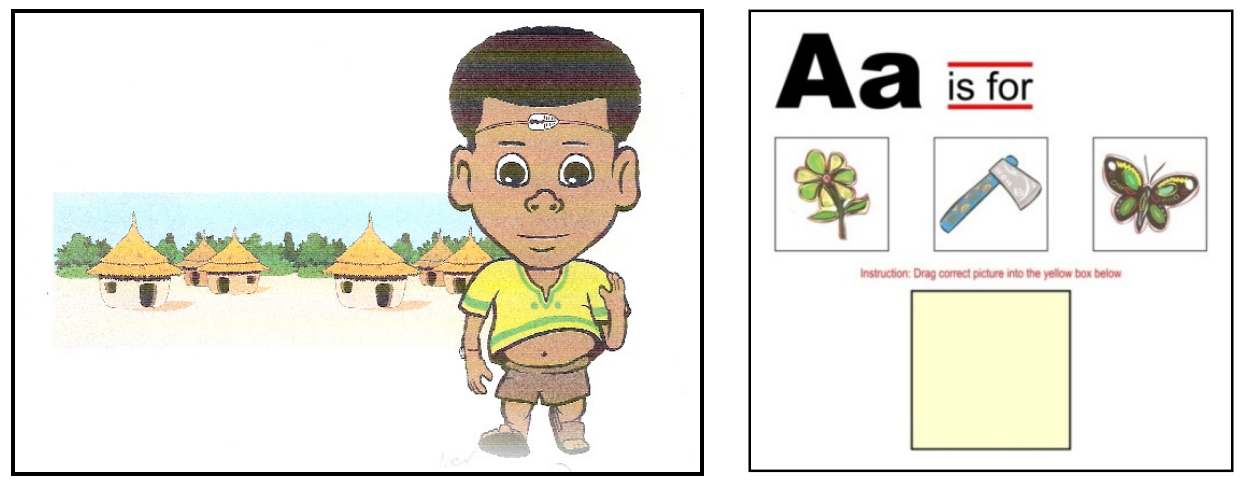

Figure 8 \& 9: Wazobia: the African Boy (i-CLAP Model's Linear Clip) \& Match-Pictures-to-Alphabets (iCLAP Model's Interactive Game) (2005)

Source: Original i-CLAP Model Test Instrument [6]

By 2006, i-CLAP was tested in Zaria among 40 children, from 4 pre-primary schools and was subsequently defended as a Ph.D. dissertation in 2007. So far, the outcome of the research has been presented in seminars/conferences at New York (2005), Nigeria (2006), Ghana (2008) and South Africa (2008) [6]. It has also been published in a few elite journals. However, the i-CLAP model is still in the formative development state and still seeking corporate partnership or grant for full implementation into the early childhood education.

\section{The Benefits of Promoting the Afrimation Industry}

It is interesting to note that in order to make these accomplishments; the 6 afrimation companies had to secure international corporate partnership, receiving international funding assistance and signed-up broadcast deals with renowned media organizations. Victor Kyalo argues that "it is important with the landing of the fiber optic cables that we...produce local digital contents and not just 'access' other people's contents" [38]. Against which backdrop, there is the need for a concerted effort by all stakeholders, towards promoting Africa's growth and future development, which can also be carried out through the production of standard digital contents. These benefits can be seen in ways that include:

- Repackaging Africa's Rich Cultural Heritage: These Afrimation companies used advanced digital technology tools for repackaging and disseminating (i.e. preserving, promoting and projecting) Africa's rich cultural heritage in forms of animated television commercials and alternative indigenous educational technology resources. Notably, some of these companies were able to strike international broadcast deals with prominent media organizations likes of CFI, the BBC, Disney and HBO satellite channels. Having developed 'standard' African folkloric tales for local and global consumption, thereby adding diversity to the current global digital contents. This is no doubt a step ahead of the traditional dissemination of cultural ideologies through books, trade expos and the museum platforms. The African video-ondemand (VoD) internet platform with its headquarters in Dakar, Senegal, aims to help African film makers, producers and distributors disseminate their content globally and provide more visibility for Africa's film-makers. Adding that the initiative's main sponsor is the African, Caribbean and Pacific (ACP) Films, the ACP-EU co-operation programme to support the cinema and audiovisual sector in ACP countries [9]. 
International Journal of Computer Graphics \& Animation (IJCGA) Vol.2, No.2/3, July 2012

- Enhancing International Business Partnership: Of course, international partnership has immediate and long-term socio-economic benefits on Africa and its people. Socially, this provided cooperative and mentorship opportunities between local and international organizations. For instance, relationships with organizations like Tiger Aspect Productions, UK, Animated Family Films Incorporated, Florida and Rochester Institute of Technology (RIT), Rochester, New York, served as springboard for uplifting some of these local projects to international digital frontiers. Furthermore, business partnership with international organizations offered local companies the needed leverage for penetrating the international animation business frontiers, thereby increasing their capacities to both secure international funding assistance and or bigger business deals. For instance, Triggerfish Studio and the $i$ CLAP model project both received funding assistance from both local and foreign organizations, towards alleviating the cost of their accomplishments.

- Render Auxiliary Professional Services: These companies indulged in rendering auxiliary professional commercial services for local and international clients, ranging from the production of TV commercials, film titles sequences, new media designs, alternative indigenous instructional resources and designs for social media platforms. Through which process more funds were acquired to complement the operational capacities of these companies. Also, the development of skills and capacities to hundreds of local creative talents and emerging digital technologists, among who are artists, designers, scriptwriters, video editors and computer programmers.

For instance, the creative content economy, which includes the broadcast, film, music, art, publishing, advertising, animation and gaming industries, contributed in Kenya an estimated Sh25 billion ( $\$ 30$ million) to the economy last year [ ]. But this amounted to just one percent of the economy, compared to 5.1 percent in Jamaica, 11.2 percent in the US and four percent in Latvia. According to Verizon White Paper [59] as advanced technologies reach emerging new markets, they allow hundreds of millions of people to earn wages that can lift them out of poverty and place them into a new, rapidly growing middle class.

- Provision of Offshore Outsourcing Services: Some of the companies also offered offshore animation outsourcing services for some European and American companies seeking to contract out some or all of their animation projects to other companies at lower-costs. Greenhouse [24] affirms that when outsourcing involves the contracting of service operations to foreign countries, it is called offshore outsourcing. It is important to note that some of the local companies offered outsourcing services similar to what is found in Japan, China and India, which enhanced their revenue bases, technical competences, employment creation capacities and export earnings. Hence, the development is considered very positive on Africa's digital technology landscape.

It is noted that the aforementioned benefits are evidences that the African heritage is not about violence, starvation, diseases, crime or corruption, nor are Africans comfortable with being donor recipients or adherents of unscientific methods in solving problems. Arowolo [3] laments that "two hundred years or so of colonization were not only destructive in terms of cultural heritage and values for which Africa was famous before colonialism, but also precariously retrogressive as the continent was robbed of decades of opportunities for self-development, self-government and self-styled technological developmental pace." According to [12] article 1 of both the International Covenant on Civil and Political Rights (ICCPR) and the International Covenant on Economic, Social and Cultural Rights (ICESCR) recognize the right to cultural self-determination 
International Journal of Computer Graphics \& Animation (IJCGA) Vol.2, No.2/3, July 2012

in the same words, by virtue of that right they freely determine their political status and freely pursue their economic, social and cultural development.

\section{Partnership Strategies for Afrimation Development}

It is apparent that in order to meet changing operational circumstances, new technologies, new competitors and new economic and social challenges, Africa's animation companies required new business strategies. Hence, a number of them had to restructure their business models, the essence being towards exerting the most impact on the local audience as well as frontiers beyond Africa. According to Investopedia [31] "a business models refers to the plan implemented by a business on how to generate revenue and make profit from its operations." Mutua [38] affirms that worldwide, digital content activities are transforming traditional industry structures and business models. These changing tides brought to bear new business models that took cognizance of the indispensability of corporate partnership as a blueprint for the industry's success. Interestingly, the British Prime Minister, Tony Blair, in initiating the Commission for Africa in 2004, recommended the need to work together in partnership as a new era [58]. Against which backdrop, to help in developing, implementing and sustaining its operations in West Africa, Sesame Workshop consented to the formation of strategic partnerships [18].

Therefore, a fundamental component of the new business strategy, was securing parts of their revenues through funding assistance in forms of grants, donations or contributions from organizations abroad. Both $i$-CLAP and Zambezia received such assistance. In terms of production locations, it is indicative that Tinga Tinga Tales, Kabongo, Zambezia, i-CLAP and The Lion of Judah were partly produced locally and partly with their corporate partners abroad. Certainly, Kabongo's post-production work was carried out in France and i-CLAP's entire Computer Graphics work in Rochester, New York.

\section{Afrimation and the African Renaissance Agenda}

A significant emerging trend evident among contemporary afrimation businesses was to establish corporate partnership with relevant international companies or organizations for technical training and financial supports. Through this process the selected local companies were strengthened and provided a platform to project their unique creative merchandises onto the global digital technology arena. Wherefrom, some of them met venture capitalists and struck decent promotional, partnership or sale deals. In concordance with the Economic Development Directorate [17] which ascertains that the continent needs serious investments to develop its infrastructure base and local innovative approaches towards mobilizing its human and material resources.

Also, the African Information Society Initiative (AISI) and the New Partnership for African Development (NEPAD) posit that the international community, such as development agencies and donors, are key partners in promoting ICTs for development in Africa. It is no doubt that these new strategies offer a means towards reinvigorating Africa's frail but promising local content industry and sustaining its operations. Of course, this is in harmony with the 'publicprivate-partnership' (PPP) agenda of the New Partnership for African Development (NEPAD), which [43] embraces a holistic integrated sustainable development initiative for the social and economic revival of Africa. The essence is towards discouraging the total reliance on government 
International Journal of Computer Graphics \& Animation (IJCGA) Vol.2, No.2/3, July 2012

and local markets by African entrepreneurs, instead looking to set up partnerships with international business organizations as stepping stones for reaching the global marketplace.

Evidently, earlier local business strategies seemed to have evolved mainly around acquisition of sustainability funding from home-based private organizations and the public sectors, with little or no external private sector involvements. That status needed to be overhauled in order for Africa to make meaningful contributions to the global development agenda. However, today the adoption of new partnership strategies has brought about sponsorship, training and social network privileges, never before availed to Africa's digital technology developers. For instance, are series of internationally funded animation trainings, the most significant being the UNESCO/CFI funded Africa Animated workshops, which took place in 2004 and 2005 across Kenya, Tanzania and South Africa. Further supports for the events emanated from partners like: The French Cooperation; UNICEF's Sara Communication Initiative; Bournemouth University, UK; Parsons School of Design, USA and Concordia University, Canada.

These trainings involved dozens of local animators who produced quite a handful of short animation film concepts, some of which have won series of awards in international festivals. Also, renowned volunteer professionals include: Cilia Sawadogo (Canada); Anezka Sebek and Nina Paley (USA); Paula Callus (UK). Also, local co-trainers like: Alonso Aznar and Kwame Nyongo. Guest lecturers included: Emma Kaye (South Africa); Silvia Bazzoli (Italy); Mshai Mwangola (Kenya) [14].

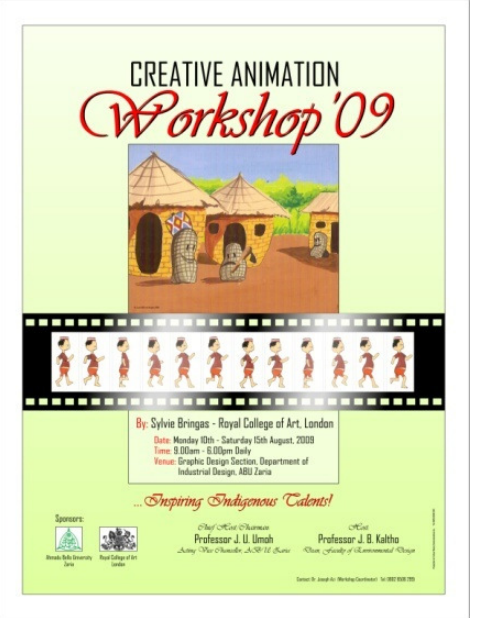

Figure 10: Poster for the 2009 Creative Animation Workshop in Zaria, Nigeria Source: Poster Designed by Dr. Joseph Azi (in 2009)

Other significant complementary training workshops that took place recently within this African digital renaissance period included: Anamazing, Life Changing Blender Training, SHOOT! and Creative Animation Workshop. It is noteworthy, that the Creative Animation workshop took place in 2009 under the theme 'Inspiring Indigenous Talents' (see Figure 10 above for event poster). It was conducted by Sylvie Bringas, an animator from the Royal College of Art and Westminster University both in London. While it would cost about $\$ 20,000$ to $\$ 30,000$ annually to acquire animation training abroad (based on RIT, Rochester's fees), these trainings were conducted free. Interestingly, the seeds sown during these series of training activities have germinated and produced dozens of young indigenous creative animators, who have blazed new trails in the business in Africa. Through setting up contemporary animation studios and producing 
International Journal of Computer Graphics \& Animation (IJCGA) Vol.2, No.2/3, July 2012

exceptional contemporary African indigenous digital contents, as well as provide training for enthusiastic youths towards sustaining the set legacies.

\section{Conclusion}

Despite of Africa's multifaceted predicaments like wars, diseases and corruption, its rich cultural heritage is a potential resource for its local content development industry towards transformation and growth. This assertion is supported by the recent developments in digital technology in Africa, exemplified by the accomplishments made by contemporary animation projects like Kabongo, Tinga Tinga Tales, Zambezia to mention but a few. This Africa's digital revolution was triggered by the series of internationally funded training workshops, made possible through partnership, collaborative and mentorship opportunities availed to local animation artists, designers and scriptwriters.

The goal of which was to enhance the technical knowhow of local animation practitioners and avail them with new technical skills and venture creation opportunities towards advancing the structure of the creative industry in Africa. Of course, digital technology requires high technical competence that converged between art, design, technology and cultural anthropology, as well as other relevant disciplines. In fact, this article concludes that this development can provide the needed impetus for a positive transformation of Africa's rich cultural heritage into contemporary globally competitive digital contents. This is especially essential with a view towards advancing the African Renaissance agenda, in this digital technology revolution era. Thereby, enhancing the quality of its people's life and turning the region into a dynamic and successful economy and hub for foreign investors.

\section{References}

[1] Adams, D. and Goldbard, A. (2008). Community, Culture and Globalization. Community Arts Network Reading Room (CAN)/Art in the Public Interest (API) Publications.

[2] Ashby, E. (2011). Magic Cellar (HBO Family). Common Sense Media Inc. http://www.commonsensemedia.org/tv-reviews/Magic-Cellar.html.

[3] Arowolo, D. (2010). The Effects of Western Civilization and Culture on Africa. Afro Asian Journal of Social Sciences. Volume 1, No. 1 Quarter IV, ISSN 2229 - 5313. http://onlineresearchjournals.com/aajoss/art/53.pdf

[4] Atilola, O. \& Olayiwola, F. (2011). Mind Frames in Nollywood: Frames of Mental Illness in Nigerian Home Videos. Research Journal of Medical Sciences Year. Volume: 5, Issue: 3, Pp 166171.

[5] Azi, J. I. (2006). Interactive Child Learning Aid Project (i-CLAP): Design and Development of an Indigenous Instructional Multimedia Model for Nigeria. International Journal of Education and Development using Information and Communication Technology (IJEDICT). Vol. 2. No. 4. Pp 137143. ISSN: 1814-0556. http://ijedict.dec.uwi.edu/viewarticle.php?id=175\&layout=html.

[6] Azi, J. I. (2007). Interactive Child Learning Aid Project (i-CLAP): Developing an Indigenous Multimedia Model for Enhancing Pre-Primary Education in Nigeria. An Unpublished Ph.D. Thesis, Ahmadu Bello University (ABU), Zaria.

[7] Azi, J. I. (2010). The African Renaissance through Digital Imaging Project (ARDIP): Towards Developing Indigenous Animation for Nigeria. Unpublished Paper Presented at Saunders Business School, Rochester Institute of Technology (RIT) Rochester, New York 
International Journal of Computer Graphics \& Animation (IJCGA) Vol.2, No.2/3, July 2012

[8] Azi, J. I., Aboderin, A. O., Nkom, A. A. and Schweppe, M. (2008). Dialogue on Integrating Indigenous Contents and Instructional Technology Application in Nigeria: The "i-CLAP" Model Experiment. A Paper Presented at Emerge Conference at South Africa. Theme: Professionalizing Practices.

[9] Balancing Act (2011). AfricanFilms.tv Launches in June 2011 with 500 VoD Titles on NonExclusive Basis. http://www.balancingact-africa.com/news/broadcast/issue-no102/topstory/africanfilmstv-launc/bc

[10] Balancing Act (2012). Buni TV: A New VoD Platform for African Independent Producers. http://www.balancingact-africa.com/news/broadcast/issue-no129/top-story/buni-tv-a-new-vod-pl/bc

[11] Bargblor, E. Z. (2003). Africa's Contribution to Contemporarily Western Civilization. The Perspective. Assata Speaks. Georgia. http://www.assatashakur.org/forum/they-all-look-like-allthem/26410-africas-contribution-contemporarily-western-civilization.html

[12] Bhattacharjee, K. (2001). Local Content Rules in Broadcasting. http://www.article19.org/data/files/pdfs/publications/local-content-rules.pdf

[13] Bynum (2010). Africa Animation in 'Tinga Tinga Tales'. http://www.animationinsider.net/staff.php\#4

[14] Callus, P. (2007). African Animation. http://www.paulacallus.blogspot.co

[15] Dawes, B. (2011). The Lion of Judah. IMDb.com, Inc. http//:www.imdb.com/search/title?plot_author=BrantDawes\&view=simple\&sort=alpha.

[16] Discop (2012)

[17] Economic Commission for Africa (2001). New Partnership for African Development (NEPAD) ICTs in the development process.

[18] Economic Development Directorate (2007). Swindon Economic Development Vision and Framework. Economic Development Directorate, Premier House, Swindon. http://ww5.swindon.gov.uk/moderngov/mgConvert2PDF.aspx?ID=11626\&J=1

[19] ECD, Sesame Workshop (2004). Sesame Street in West Africa: A Feasibility Study. American Institutes for Research (AIR). http://pdf.usaid.gov/pdf_docs/PNADD971.pdf

[20] Encarta (2009). Primitive Music and Dance. Microsoft Student [DVD]. Redmond, WA: Microsoft Corporation.

[21] eNowNow (2009). Nigeria Rank Second Largest Film Industry By UNESCO. http://www.enownow.com/news/story.php?sno=3334

[22] Essoungou, A. M. (2010). Africa Renewal Magazine: A Social Media Boom Begins in Africa. United Nations Africa Renewal Online. http://www.un.org/en/africarenewal/vol24no4/social-mediaboom.html

[23] Frost, E. L. (2000). European Union Studies Center: From Rockets to Religion: Understanding Globalization.

[24] Global Policy Forum (2008). Defining Globalization. Global Policy Forum (GPF) Monitors Policy Making at the United Nations. http://www.globalpolicy.org

[25] Greenhouse, S. (2009). Outsourcing. Microsoft Student [DVD]. Redmond, WA: Microsoft Corporation.

[26] Greenleaf, V. (2011). 'Lion of Judah' Animated Movie Premieres in June. Charisma News Online. http://www.charismamag.com/index.php/news/31147-lion-of-judah-animated-movie-premieres-injune.

[27] HBO Family (2012). Magic Cellar. Home Box Office, Inc. http://www.hbofamily.com/programs/magic-cellar.html. 
International Journal of Computer Graphics \& Animation (IJCGA) Vol.2, No.2/3, July 2012

[28] http://wn.com/The_General_Assembly_of_Diseases_Scenerios_from_the_Sahel

[29] http://www.animationinsider.net/article.php?articleID=2266

[30] http://www.google.com.ng/imgres?imgurl=http://www.frankierants.com/wpcontent/uploads/2011/03/tinga-tinga-tales/

[31] Internet Usage Statistics (2011). World Internet Users Statistics News and World Population Stats. Miniwatts Marketing Group, Worldwide. Nielsen Online.

http://www.internetworldstats.com/stats.htm

[32] Investopedia (2012). Definition of Business Model. ULC. http://www.investopedia.com/terms/b/businessmodel.asp

[33] Iwunze, C. (2011). Mark of Uru: A Gem in the Nigerian Animation Industry. African Screens. http://www.africanscreens.com/africanfilms/read_interview.php?interviews_id=22

[34] Kaloki, T. (2011). The Creative Economy: Which Way for Africa's Future. Arterialnetwork. http://arterialnetwork2011.blogspot.com/2011/08/creative-Economy-which-way-for-africas.html

[35] Mbaye, J. (2012). Conference Report: African Creative Economy - A New Priority for the Continent. LSE Engagement with Africa. http://blogs.lse.ac.uk/africaatise/2012/02/09/conference-report-africancreative-report-african-creative-economy-a-new-priority-for-the-continent/

[36] McKee, N. and Clark, C. (1996). Meena and Sara: Two Characters in Search of a Bright Future for Girls. Animation World Magazine (AWM).

http://www.awn.com/mag/issue1.2/articles1.2/mckeeclark1.2.html

[37] McKenzie, W. (2006). Multiple Intelligences and Instructional Technology. Every One Learns Pedagogy, Technology, Motivation. http://everyonelearns.blogspot.com/2006/04/multipleintelligences-and.html

[38] Mitchell, W. (2007). Global entertainment industry to be worth $\$ 2$ trillion by 2011. ScreenDaily. http://www.screendaily.com/global-entertainment-industry-to-be-worth-2-trillion-by2011/4033233.article.

[39] Mutua, W. (2010). Press Release: Kenya ICT Board Launches Ksh 300M (US\$4 Million Grant to Promote Development of Local Digital Content and Software Application. Afrinnovation. http://afrinnovator.com/blog/2010/06/02/press-release-kenya-ict-board-launches-ksh-300mus4million-grant-to-promote-development-of-local-digital-content-and-software-applications/

[40] Mutua, W. (2011). A Discussion on Local Content within the African Context. Afrinnovator. http://afrinnovator.com/blog/2011/12/06/a-discussion-on-local-content-within-the-african-context/

[41] Mutua, W. (2012). Talking about Africa's Digital Content Future. Afrinnovator. http://afrinnovator.com/blog/2012/04/21/talking-about-africas-digital-content-future/

[42] NASCIO (2006). Keys to Collaboration: Building Effective Public-Private Partnerships. The National Association of State Chief Information Officers (NASCIO) Corporate Leadership Council (CLC). Issue Brief.

[43] Newman, J. L., Assefa, M., Kevin, S. and Robert, S. (2009). Africa. Microsoft Student [DVD]. Redmond, WA: Microsoft Corporation.

[44] Ogunduyile, S. R. and Akinbogun, T. L. (2006). Industrial Design Status and the Challenges to National Development in Nigeria. The SABS Design for Development Lekgotla.

[45] Okon, A. (2010). The Nigerian Movie Industry (Nollywood) - The Origin (History). Ezine. http://ezinearticles.com/?The-Nigerian-Movie-Industry-(Nollywood)---The-Origin(History)\&id $=4226728$ 
International Journal of Computer Graphics \& Animation (IJCGA) Vol.2, No.2/3, July 2012

[46] Olajide, S. B. (2010). Folklore and Culture as Literacy Resources for National Emancipation. International Education Studies. Vol. 3, No. 2; May 2010. www.ccsenet.org/ies in Federal Republic of Nigeria (2004). National economic employment and development strategy (NEEDS). Abuja, Nigeria: Planning Commission.

[47] Pickett, P. (2012). What is Offshore IT Outsourcing? About.com. http://jobsearchtech.about.com/od/workplaceissues/f/What_Is_Offshore_Outsourcing.htm

[48] Quist-Adade, C. and van Wyk, A. (2007). The Role of NGOs in Canada and the USA in the Transformation of the Socio-Cultural Structures in Africa. Africa Development, Vol. XXXII, No. 2, pp. 66-96. Council for the Development of Social Science Research in Africa. ISSN 0850-3907. http://www.codesria.org/Links/Publications/ad2-07/adade-quisti.pdf

[49] Riggs, F. W. (2000). Globalization Key Concepts. COCTA Panel on Globalization, World Sociology Congress, Montreal.

[50] Sauvalle, P. (2005). Putting Africa on the Animation Map: The Story of Pictoon, Senegal. World Intellectual Property Organization (WIPO) Online Magazine.

[51] http://www.wipo.int/wipo_magazine/en/2005/05/article_0004.html

[52] Squidoo (2010). The Lion Of Judah Movie - Squidoo. http://www.squidoo.com

[53] Tiger Aspect (2010). Claudia Lloyd: Head of Animation \& Children's Comics. Tiger Aspect Productions Ltd. http://www.tigeraspect.co.uk/?page_id=2218.

[54] TingaTinga 2 (2011). TingaTinga 2 - Original Paintings from Tanzania. http://www.insideafricanart.com/artists\%20main\%20pages/Tinga\%20Tinga\%202.htm.

[55] Triggerfish (2010a). http://www.triggerfish.co.za/

[56] Triggerfish (2010b). Zambezia Featured in Animation Magazine.

[57] http://triggerfishanimation.blogspot.com/2010/09/zambezia-featured-in-animation-magazine.html

[58] Triggerfish (2010c). Zambezia Takes Flight! Www.animationsa.org/community/pressreleases/triggerfish/zambezia-takes-flight.

[59] United Nations Conference on Trade and Development (2012). Mobile Phone Access Varies Widely in sub-Saharan Africa. Gallup. http://www.gallup.com/poll/149519/mobile-phone-access-varieswidely-sub-saharan-africa.aspx.

[60] Unwin, T. (2005). Partnerships in Development Practice: Evidence from Multi-stakeholder ICT4D Partnership Practice in Africa. UNESCO Publications for the World Summit on the Information Society, France.

[61] Verizon White Paper (2012). Success in Emerging Markets: ICT as Part of a Strategic Vision. http://www.verizonbusiness.com/resources/whitepapers/wp_keys-to-success-in-emergingmarkets_en_xg.pdf

[62] Wallace, A. (2010). Animation History in Africa. http://www.awphoto.biz/Animation\%20history\%20in\%20Africa.pdf

[63] www.omg-facts.com/view/Facts/24126

[64] Yuan, Z. (2005). Features and impacts of the internationalization of R\&D by transnational corporations: China's case. In Globalization of R\&D and Developing Countries: Proceedings of the Expert Meeting. United Nations Conference on Trade and Development, Geneva. http://www.unctad.org/en/docs/iteiia20056_en.pdf 
International Journal of Computer Graphics \& Animation (IJCGA) Vol.2, No.2/3, July 2012

\section{Author}

Dr. Joseph Izang Azi is a Lecturer with the Department of Industrial Design (Graphics), Ahmadu Bello University, Zaria, Nigeria. He is currently a Master's Degree student in Computer Graphic Design at the College of Imaging Arts and Sciences, Rochester Institute of Technology, Rochester, New York, where he was both a Fulbright and MacArthur Fellows in 2006 and 2008 respectively. He initiated the Interactive Child Learning Aid Project (i-CLAP), which he defended as a Ph.D. dissertation in 2007 and has since been his area of major research interest. 